\title{
The Illusion of Deterrence in Isaac Ehrlich's Research on Capital Punishment*
}

\author{
William J. Bowers ${ }^{\dagger}$ and Glenn L. Piercet†
}

In this critique of Professor Ehrlich's recent research on capital punishment, ${ }^{1}$ we conclude that he has failed to provide any reliable evidence that the death penalty deters murder. His data are inadequate for the purposes of his analysis and he misapplies the highly sophisticated statistical techniques he employs. We begin with an evaluation of the data he uses to measure the critical variables in his theoretical formulation and then consider flaws in his analysis which would invalidate his conclusions even if his data were adequate. We conclude by explaining how Ehrlich's analysis produces results which seem consistent with the deterrence hypothesis when in fact they are not. $^{2}$

\section{Inadequacies in Ehrlich's Data}

The credibility of Ehrlich's conclusions depends on the quality of the data he has used. For measures of the variables at the core of his theoretical analysis, he relies on the Uniform Crime Reporting System (UCRS) of the FBI. ${ }^{3}$ The behavior he seeks to explain (the dependent

- We wish to thank Andrea Carr, Elizabeth Chambers, Robert Kazarian, Phyllis Lakin, and Shari Wittenberg for their help in preparing this article. We also wish to thank the staff of the Northeastern University Computation Center for providing frequent and extended access to the computer in connection with this work. This work was supported in part by Grant No. RR07143 from the U.S. Department of Health, Education, and Welfare.

$\uparrow$ Director, Center for Applied Social Research, Northeastern University.

it Research Assistant, Center for Applied Social Research, Northeastern University.

1. Ehrlich, The Deterrent Effect of Capital Punishment: A Question of Life and Death, 65 AM. Econ. Rev. 397 (1975) [hereinafter cited as Ehrlich 1975]; I. Ehrlich, The Deterrent Effect of Capital Punishment: A Question of Life and Death, 1973 (Working Paper No. 18, Center for Economic Analysis of Human Behavior and Social Institutions) [hereinafter cited as Ehrlich 1973].

2. The findings presented here are drawn from a more extensive and detailed critique of Ehrlich's work by the present authors. Deterrence, Brutalization, or Nonsense, 1975 (unpublished mantscript, Center for Applied Social Research, Northeastern Univ.). This manuscript includes as appendixes the full regression results for equations used to estimate coefficients in the present paper (id. appendix B (on file with Yale Law Journal)) and a complete listing of the data values used in replicating Ehrlich's analysis (id. appendix C (on file with Yale Law Jourmal)).

3. Ehrlich 1975 , supra note 1 , at 406 n.10. 
variable) is the annual criminal homicide rate for the United States as reported by the UCRS, and his deterrence variables are the rates of arrest, conviction, and execution for homicide, which also come entirely or in part from the UCRS. Only if these data are sound throughout the full time period covered by Ehrlich's analysis do his findings deserve serious consideration.

\section{A. The Dependent Variable}

The FBI's national homicide statistics collected in the early years of the UCRS are unreliable. A staff report of the National Commission on the Causes and Prevention of Violence emphasizes this problem:

[M]any reporting agencies, especially in the nonurban areas, were slow in joining the UCR network; there were only 400 agencies reporting to the $U C R$ in the 1930 's, while today there are about 8,500 . Thus, trends of both violent and nonviolent crimes during the early years of the $U C R$ are highly questionable as representative of national figures. ${ }^{4}$

Furthermore, the President's Commission on Law Enforcement and the Administration of Justice warns that "figures prior to 1958, and particularly those prior to 1940 , must be viewed as neither fully comparable with nor nearly so reliable as later figures."

Ehrlich indicates that he used "readjusted" estimates of the homicide rate supplied by the FBI. ${ }^{6}$ The FBI has periodically adjusted their estimates of offenses for earlier years on the basis of recent data on offenses from jurisdictions that entered the reporting program after 1958. Yet to our knowledge there are no published indications of how the readjustments are performed. In any case, the adjustment of figures for as long ago as 40 years on the basis of the current homicide levels of agencies recently added to the sample is of dubious value.

Less problematic are the willful homicide figures compiled by the Bureau of the Census. Unlike the voluntary reporting system of the FBI, Census reports of willful homicide are mandated by law in each state. The annual collection of mortality statistics including willful homicide began in 1900, 30 years before the beginning of the FBI reporting system. By 1933, all states had met the 90 percent coverage

4. 11 Staff of the Nat'l Comm'n on the Causes and Prevention of Violence, Crimes OF VIOLENCE 17 (1969).

5. The President's Comm'n on Law Enforcemckt and Administration of Justice. Crime and Its Impact-AN Assessment 20 (1967).

6. Ehrlich 1975 , supra note 1 , at 406 . 
requirement for admission to the national Vital Statistics program. ${ }^{7}$ Thus, the Census homicide statistics for the nation have been relatively complete since the early 1930 's. $^{8}$ Furthermore, the classification of "willful homicide" has remained essentially constant over time. ${ }^{0}$ For these reasons, perhaps, the Census homicide figures have gained a reputation for reliability, and have been used more widely than the FBI figures in previous studies of the deterrent effects of capital punishment. ${ }^{10}$

If both FBI and Census data provided accurate estimates of the homicide rate, the statistics would, of course, agree. Table $I^{11}$ shows that the figures drawn from the two agencies are reasonably well correlated except during the 1930's, when the FBI's reporting system was in its inception. Notably, the FBI homicide estimates are 15 percent below the Census figures for the 1930's, whereas the difference is only about three percent lower for the period after 1940. By all indications, these discrepancies are the result of inadequate sampling, reporting, and estimating in the early years of the UCRS.

7. I U.S. Public Health Serv., Dep't of Health, Education, and Welfare, Vital, Statistics of the United States 1950, at 29 (1954).

8. Tests of the completeness of birth registrations made in 1940 and 1950 indicated that these statistics were, respectively, 92.5 and 97.9 percent complete. Although precise studies of the completeness of death registrations are not available for this period, the compilers of the Vital Statistics believe that they are even more complete than birth registrations. $I d$.

9. The Department of Health, Education, and Welfare reports:

Since 1900, the causes of death have been classified according to seven different revisions of the International Classification of Diseases. Each revision has produced some breaks in the comparability of cause-of-death statistics. However, homicide is among the causes for which the classifications are essentially comparable for all revisions.

National Center for Health Statistics, U.S. Dep't of Health, Education, and Welfare, HOMICIDE IN THE UNITED STATES 1950-1964, at 9 (1967).

10. E.g., T. Sellin, The Death Penalty (ALI 1959); Schucssler, The Deterrent Influence of the Death Penalty, 284 AnNals 54 (1952).

11.

TABLE I

Correlations Belween Homicide Rates Based on FBI and Census Data by Decade

Effective Period
$1933-1939$
$1940-1949$
$1950-1959$
$1960-1969$

Annual Homicide
Rates
.24
.81
.95
.98

Year to Year Changes
in Homicide Rates
-.69
.86
.76
.79

For data sources, see Appendix, nos. 1, 13.

A correlation of .24 between FBI and Census annual homicide rates for the 1930's means that there is little consistency (only six percent common variance) between the two data sets in this decade. A correlation of - .69 between year to year changes in FBI and Census homicide rates means that an increase between adjacent years in one set of figures is likely to be accompanied by a decrease between the corresponding years in the other set. 


\section{B. The Deterrence Variables}

The FBI data on arrest and conviction rates are even less reliable. The agencies reporting arrest and conviction statistics have remained a relatively small, self-selected subsample throughout most of the period during which these statistics have been compiled. Indeed, the arrest and conviction figures are based on such small and unrepresentative samples of law enforcement agencies that the FBI has made no effort to readjust earlier arrest and conviction figures on the basis of more recent returns.

As shown in Figure $1,{ }^{12}$ the number of agencies reporting arrest data did not reach 2,000, or about one-quarter of the total number of agencies, until the 1960's, and the number of agencies reporting convictions did not exceed 300 until the 1960's. The abrupt increase between 1960 and 1961 in agencies reporting convictions represents a major change in reporting practices for conviction statistics by the UCRS. Notably, in 1936, the first year in which conviction rates were

12.

Figure 1

NUMBER OF AGENCIES REPORTING ARREST AND CONVICTION STATISTICS BY YEAR

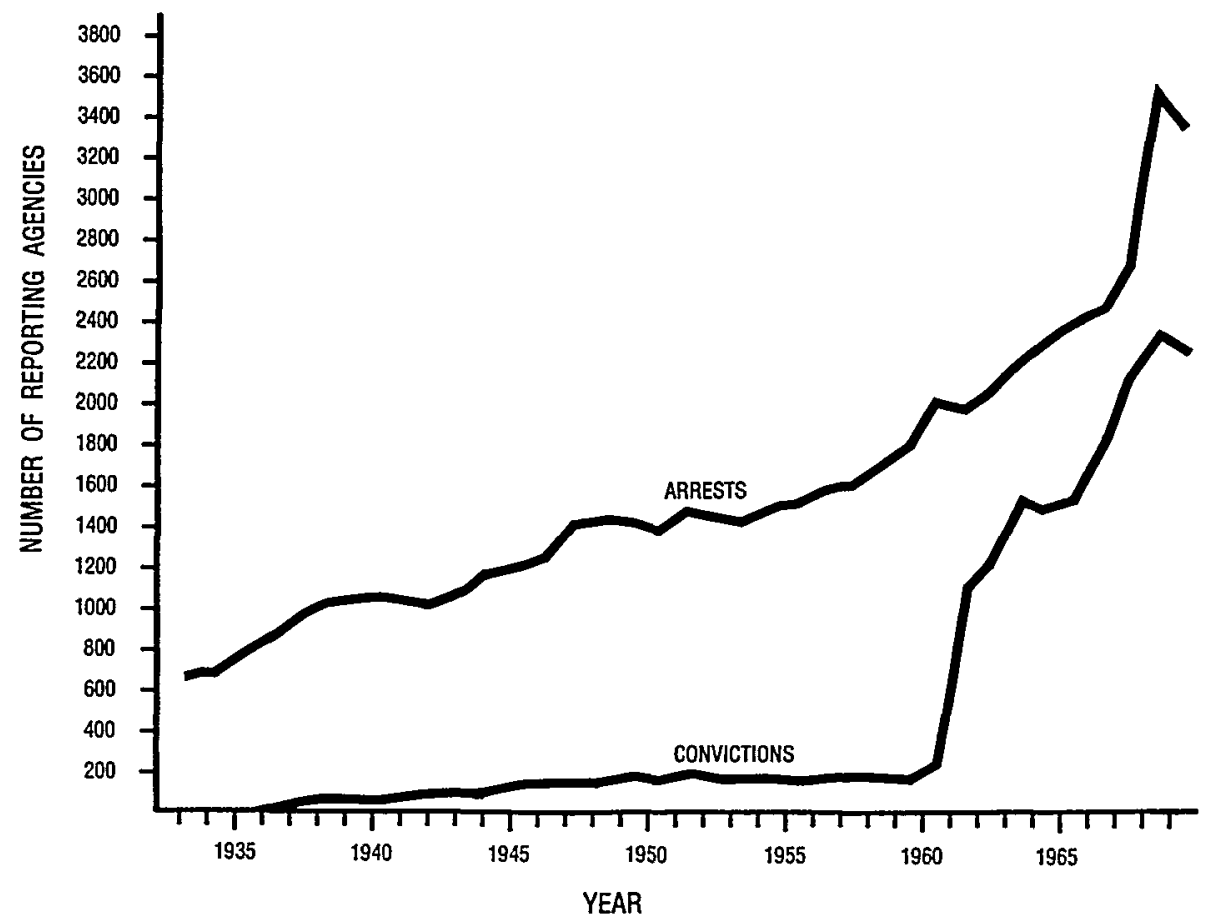

For data sources, see Appendix, nos. 2, 3. 
reported, the figure Ehrlich used as a national estimate was based on only 13 jurisdictions.

Figure $2^{13}$ shows that the average size of jurisdictions reporting conviction data declined substantially in the late 1930's and the early 1960's. According to recent evidence, conviction rates are relatively low in the nation's largest jurisdictions. ${ }^{14}$ Hence the conviction data drawn from disproportionately large jurisdictions in 1936 and 1937 are apt to underestimate the national conviction levels for these years. In fact, the reported conviction levels for these two years are far below those for other years-respectively -5.94 and -4.54 standard deviations below the mean conviction level for the period 1938-1969. Because the 1936 and 1937 conviction levels figure prominently in Ehrlich's estimation of missing conviction values for the years 19331935, the conviction rates for the entire period 1933-1937 are apt to be grossly biased in his analysis. ${ }^{15}$

13.

Figure 2

POPULATION COVERAGE PER AGENCY REPORTING

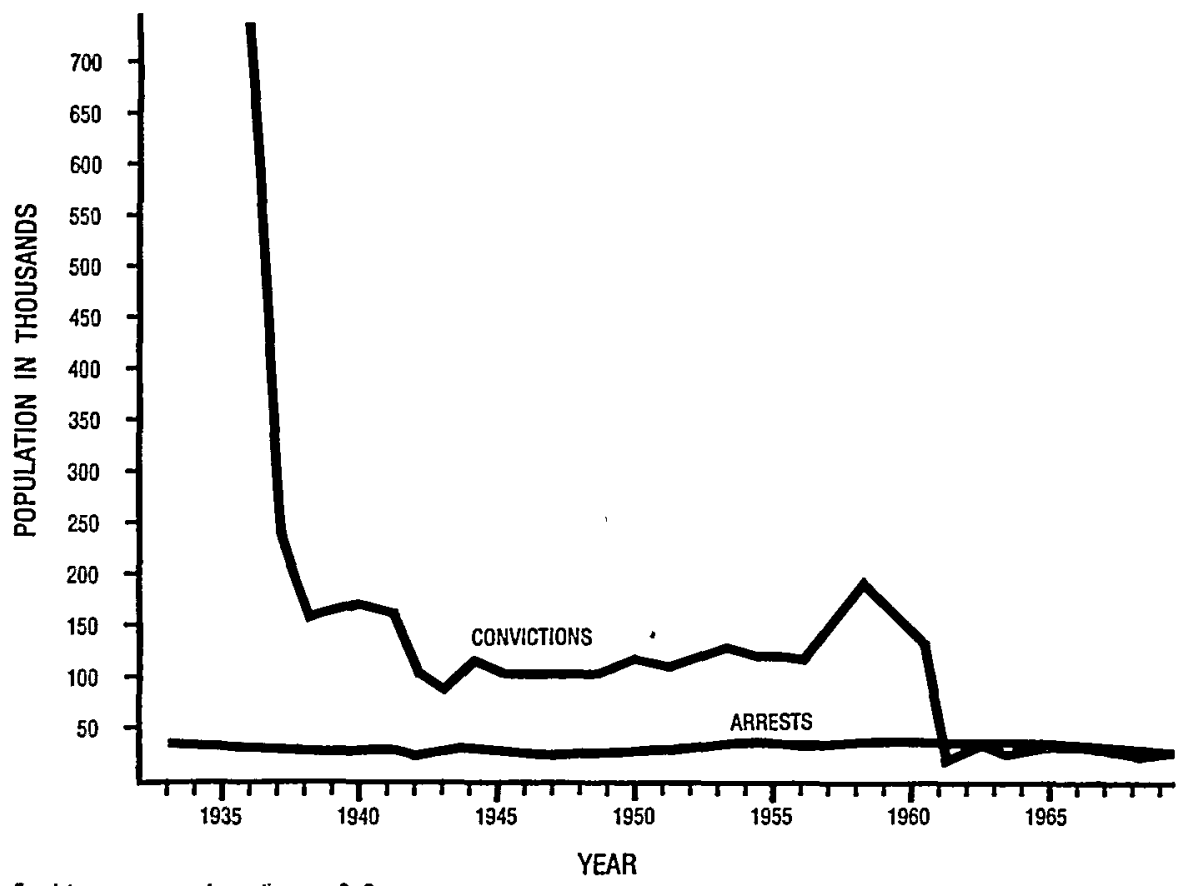

For data sources, see Appendix, nos. 2, 3.

14. In 1974 , only 31.9 percent of those charged with homicide in jurisdictions with populations of 250,000 or more were convicted, as compared to approximately 50 percent in smaller jurisdictions. Unpublished FBI data (on file with Yale Law Journal).

15. A May, 1975, memorandum prepared by Ehrlich (The Deterrent Effect of Capital Punishment: A Question of Life and Death, American Economic Review (June, 1975): 
Finally, the measurement of execution risk-the key explanatory (or independent) variable in Ehrlich's work-is confounded by the inadequacies in the homicide, arrest, and conviction data, because execution risk, as defined by Ehrlich, incorporates all three of these variables. ${ }^{16}$ Thus, like his dependent variable, all three of his deterrence variables are subject to potentially serious measurement error. While we do not contend that all of Ehrlich's data are inaccurate, we have identified substantial problems with his core variables which cast doubt on his ability to perform a meaningful regression analysis.

\section{Errors in Ehrlich's Regression Analysis}

We have independently applied Ehrlich's regression technique to comparable data. On the basis of this replication, we find that his evidence of deterrence emerges only under restrictive assumptions about

Sources of Data (on file with Yale Law Journal)) supplies the auxiliary equations he used to estimate the missing conviction values for 1933 through 1935. To show the importance of the effect of the values for 1936 and 1937 on the conviction estimates Ehrlich obtains for the missing years, we have estimated conviction rates for the years 1933-1937 on the basis of the data for the 1938-1969 period with the auxiliary equation used by Ehrlich to estimate the years 1933-1935 for the data from the 1936-1969 period. It is instructive to compare our estimated conviction rates with the corresponding values used by Ehrlich:

\begin{tabular}{|c|c|c|c|c|}
\hline & Ehrlich's C & tion Rates & Alterna & stimates \\
\hline & $\begin{array}{l}\text { Annual } \\
\text { Conviction } \\
\text { Estimates }\end{array}$ & $\begin{array}{c}\text { Standard } \\
\text { Deviations } \\
\text { from the } \\
1938-1969 \\
\text { Mean }\end{array}$ & $\begin{array}{c}\text { Annual } \\
\text { Conviction } \\
\text { Estimates }\end{array}$ & $\begin{array}{c}\text { Standard } \\
\text { Deviations } \\
\text { from the } \\
1938-1969 \\
\text { Mean }\end{array}$ \\
\hline 1937 & 30.3 & -4.54 & 43.7 & -.40 \\
\hline 1936 & 25.8 & -5.94 & 44.1 & -.29 \\
\hline 1935 & 28.3 & -5.18 & 44.1 & -.26 \\
\hline 1934 & 26.9 & -5.59 & 42.8 & -.69 \\
\hline 1933 & 30.2 & -4.58 & 43.3 & -.53 \\
\hline
\end{tabular}

We have already noted that the reported conviction rates for 1936 and 1937 are far below the mean for the 1938-1969 period. The above comparison also makes clear that these reported rates are far below the values that would be estimated for these two years by applying Ehrlich's auxiliary equation to the data for the 1938-1969 period. Furthermore, Ehrlich's estimated conviction rates for 1933-1935 are also four to five standard deviations below the mean for 1938-1969; as the alternative estimates show, they would be far higher if they were estimated on the basis of the 1938-1969 time period rather than the 1936-1969 time period.

16. Ehrlich 1975, supra note 1, at 401. All of his measures of execution risk are in various ways and degrees biased negatively with respect to the criminal homicide rate. Thus, random error in the number of homicides reported will tend to produce a negative

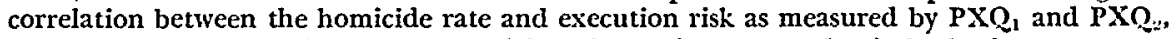
because the number of reported homicides in a given year, $Q_{t}$, is both the numerator of the homicide rate and a component in the denominator of these two execution mcasures. See Appendix, nos. 1, 4. The remaining four measures of execution risk will tend to be negatively correlated with the homicide rate as a result of autocorrelated error in the reported number of homicides, because these measures all incorporate prior (lagged) homicide levels in one way or another. 
the form of relationships among the variables and only under a narrow selection of the time period for analysis. The limitations required to obtain these results are not justified, since Ehrlich's regression model fits the data better without them. Thus, even if Ehrlich's data were free of errors, the analysis, when properly conducted, would not show that the death penalty has a deterrent effect.

\section{A. Replication of Data and Regression Results}

To ensure comparability in the replication of Ehrlich's regression analysis, we attempted to use exactly the same data as Ehrlich. Table II ${ }^{17}$ describes Ehrlich's and our variables and gives the means and

17.

Table II

Variables Used in the Regression Analysis: Annual Observations 1933-1969

(Means and Standard Deviations in Natural Logarithms)

Variable

$y_{1}\left\{\left(\frac{\mathrm{Q}}{\mathrm{N}}\right)^{0}=\begin{array}{l}\text { Crime rate: offenses known per } 1,000 \\ \text { civilian population. }\end{array}\right.$

$\mathrm{P}^{\circ} \mathrm{a}=$ Probability of arrest: clearance rates. $\mathrm{P}$ cla $=$ Conditional probability of conviction: fraction of those charged who were convicted of murder.

$\mathrm{Y}_{1}\left\{\mathrm{P}^{\mathrm{o} e} \mathrm{e}=\mathrm{c}=\right.$ Conditional probability of execution. $\mathrm{PXQ}_{1}=$ the number of executions for murder in year $t+1$ as a percent of the total number of convictions in year $t$.

$\mathrm{L}=$ Labor force participation rate of the civilian population.

$U=$ Unemployment rate of the civilian labor force.

$A=$ Fraction of residential population in the age group 14-24.

$\mathbf{Y}=$ Friedman's estimate of permanent income per capita.

$\mathrm{T}=$ Chronological time (years).

NW $=$ Percent of nonwhite residential population.

$\mathrm{N}=$ Civilian population in 1,000's. $x_{2}\left\{\begin{aligned} \mathrm{N}= & \text { Civilian population in 1,000's. } \\ \mathrm{XGOV}= & \text { Per capita (real) expenditures on all } \\ & \text { governments in million dollars. }\end{aligned}\right.$

XPOL $-1_{1}=$ Per capita (real) expenditures on police in dollars lagged one year.

\begin{tabular}{|c|c|c|c|}
\hline $\begin{array}{c}\text { Our } \\
\text { Mean }\end{array}$ & $\begin{array}{c}\text { Ehrlich's } \\
\text { Mrean }\end{array}$ & $\begin{array}{c}\text { Our } \\
\text { Standard } \\
\text { Deviation }\end{array}$ & $\begin{array}{l}\text { Ehrlich's } \\
\text { Standard } \\
\text { Deviation }\end{array}$ \\
\hline-2.853 & -2.857 & .156 & .156 \\
\hline 4.497 & 4.997 & .038 & .038 \\
\hline 3.742 & 3.741 & .172 & .175 \\
\hline .172 & .176 & 1.748 & 1.749 \\
\hline-.544 & -.546 & .029 & .030 \\
\hline 1.743 & 1.743 & .728 & .728 \\
\hline-1.759 & -1.740 & .122 & .118 \\
\hline 6.889 & 6.868 & .337 & .338 \\
\hline 2.685 & 2.685 & .867 & .867 \\
\hline-2.216 & -2.212 & .061 & .063 \\
\hline 11.944 & 11.944 & .161 & .161 \\
\hline-7.753 & -7.661 & .256 & .501 \\
\hline 2.200 & 2.114 & .146 & .306 \\
\hline
\end{tabular}

For data sources, see Appendix and Ehrlich 1975, supra note 1, at 409. In his memorandum, supra note 15, Ehrlich indicated that the mean of $\mathrm{P}^{\circ} \mathrm{a}$ is incorrectly stated in his table, and that its true value is 4.497 . 
standard deviations of their logarithms. In most cases, our means and standard deviations correspond quite closely to Ehrlich's. For 11 of the 13 variables, they differ by no more than three percent, and generally by less than one percent. Differences of two or three percent may indicate that where alternates were available we chose a different data source than Ehrlich did. The two variables that show discrepancies of greater than three percent between the two data sets-the indexes of total per capita expenditures of governments ("XGOV") and of per capita expenditures on police ("XPOL-1")-differ primarily in standard deviations. ${ }^{18}$ In all cases where discrepancies exist, however,

18. Ehrlich's memorandum, supra note 15 , describes the procedures that he used in obtaining his variables. For $\mathrm{XGOV}$ and $\mathrm{XPOL}_{-1}$, the two variables with significant differences between the two data sets, we believe that our measures more faithfully reflect Ehrlich's definitions of the variables. Although Ehrlich described XGOV as per capita expenditures of local, state, and federal governments, his memorandum indicates that he actually used government purchases of goods and services and a price deflator for government purchases, instead of government expenditures and an appropriate price deflator. His memorandum also indicates that he failed to exclude defense purchases or expenditures. This is a serious oversight since defense expenditures and purchases represent resources not available for law enforcement activity. Our measure is bascd on government expenditures and excludes defense expenditures and purchases.

It was virtually impossible to replicate XPOL-1 exactly because Ehrlich used an unspecified auxiliary regression equation to estimate unavailable police expenditure data for odd years prior to 1952. Furthermore, his memorandum indicates that he used a price deflator for government purchases rather than a price deflator for government expenditures, as we did.

We constructed two other variables differently than Ehrlich did. While " $A$ " is described as the proportion of the residential population aged 14-24, Ehrlich's memorandum reveals that he used the number of 14- to 24-year olds in both the residential population and the armed forces overseas as a proportion of the total residential population. This is clearly inappropriate since youngsters in this age group overseas cannot contribute to the domestic homicide rate. The slightly greater standard deviation of our measure based exclusively on residential population figures undoubtedly reflects movements of this age group in and out of the country during the war years.

Secondly, "BW" is described as the proportion of nonwhites in the residential population, but Ehrlich's memorandum indicates that he took the number of nonwhites in the total population as a proportion of all those in the residential population. Moreover, he used annual estimates of the nonwhite population from the Current Population Reports for the 1960's (see Appendix, no. 1), instead of readjusted estimates based on the 1970 decennial censuses. Again, our measure, based exclusively on residential population figures and readjusted annual estimates, is a more accurate representation of the variable as originally defined.

For further evidence of comparability between the two data sets, note the values of corresponding correlation coefficients for the period 1934-1969:

\begin{tabular}{|c|c|c|}
\hline & $\begin{array}{l}\text { Ehrlich's } \\
\text { Correlations }\end{array}$ & $\begin{array}{c}\text { Our } \\
\text { Correlations }\end{array}$ \\
\hline $\mathrm{PXQ}_{1}$ by $\mathrm{P}^{\circ} \mathrm{a}$ & -.028 & -.029 \\
\hline $\mathrm{PXQ}_{1}$ by $\mathrm{P}^{\circ} \mathrm{c} \mid \mathrm{a}$ & -.19 & -.181 \\
\hline $\mathrm{PXQ}_{1}$ by $\left(\frac{\mathrm{Q}}{\mathrm{N}}\right)^{\circ}$ & .140 & .133 \\
\hline $\mathbf{P X Q}_{2}$ by $\left(\frac{\mathrm{Q}}{\mathrm{N}}\right)^{0}$ & .083 & .077 \\
\hline $\mathbf{P X Q}_{1-1}$ by $\left(\frac{\mathrm{Q}}{\mathrm{N}}\right)^{\circ}$ & .096 & .077 \\
\hline
\end{tabular}


we have checked our data carefully, and we are satisfied that we have accurate measures of the variables.

With these data, we have reproduced Ehrlich's basic regression analysis. Table III $^{10}$ contains the estimated effects of six different measures of execution risk on the criminal homicide rate. The effects are represented by partial regression coefficients (or elasticities ${ }^{20}$ ), and their statistical significance is indicated by the ratio of these coefficients to their standard errors-the $t$ values of the coefficients. ( $t$ values of more than 2.0 indicate statistically significant relationships between the dependent and independent variables. $)^{21}$

The six measures of execution risk are alternative ways of representing the conditional probability of execution given conviction for murder. In five of the six measures, Ehrlich incorporates a delay between conviction and execution by dividing the number of executions in one year by the estimated number of convictions in the previous year. ${ }^{22}$ In two cases, ${ }^{23}$ he estimates execution risk at a given point in time in terms of the numbers of executions and convictions over a prior period of three or four years. ${ }^{24}$

19.

Table III

Estimated Effects of Execution Risk on the Criminal Homicide Rate

\begin{tabular}{|c|}
\hline $\begin{array}{l}\text { Six Alternative } \\
\text { Measures of } \\
\text { Execution Risk }\end{array}$ \\
\hline $\begin{array}{l}\text { PXQ } \\
\text { PXO }_{2} \\
\text { PXQ }_{1-1} \\
\text { TXQ }_{1} \\
\text { PDL }_{1} \\
\text { PXO. }\end{array}$ \\
\hline
\end{tabular}

$\begin{array}{ccc}\begin{array}{c}\text { Effective } \\ \text { Period }\end{array} & \begin{array}{c}\text { Partial } \\ \text { Regression } \\ \text { Coefficients }\end{array} & \mathrm{t} \\ 1935-1969 & -.018 & \text { Values } \\ 1935-1969 & -.068 & -.69 \\ 1936-1969 & -.023 & -3.15 \\ 1938-1969 & -.059 & -1.12 \\ 1939-1969 & -.065 & -2.76 \\ 1935-1969 & -.004 & -3.45 \\ & & -.113\end{array}$

The definitions of these variables axe contained in Ehrlich 1975, supra note 1, at 406.09.

20. When the execution and homicide variables are in logarithmic form, see pp. 199-200 infra, the partial regression coefficients indicate the elasticity of the homicide rate with respect to execution risk-that is, the percentage change in the homicide rate that can be expected from a one percent change in execution risk. Thus, an elasticity of -.068 (associated with $\mathrm{PXQ}_{2}$ ) means that a one percent increase in this measure of execution risk can be expected to yield a decrease of .068 percent in the homicide rate.

21. A $t$ value of 2.0 is generally taken as an indication of statistical significance because if the true value of the regression coefficient were actually zero, an estimated regression coefficient with a $t$ value greater than 2.0 would only occur approximately five times out of 100 . A $t$ value greater than 2.0 is required for this level of statistical significance when the number of data observations exceeds the number of explanatory variables by five or less.

22. $\mathrm{PXO}_{2}$ does not incorporate such a delay.

23. $T X Q_{1}$ and $\mathrm{PDL}_{1}$.

24. Two of Ehrlich's regression equations- $P X Q_{1-1}$ and $T X Q_{1}$ in his Table 3, Ehrlich 1975, supra note 1, at 410 -appear to be either misspecified or mislabeled in terms of the effective period of analysis. Given his data and analytic procedures, 1935 is the earliest possible beginning date for a regression analysis using any of the measures of execution risk. The first stage regression estimates of arrest and conviction rates cannot be ob- 
Table III shows a negative value for the regression coefficient associated with each of the six measures of execution risk. That is, the results of this initial regression analysis appear to indicate that, other things being equal, as the risk of execution among convicted offenders increases, the homicide rate decreases and, conversely, as execution risk declines, the homicide rate rises. For three of the six measures of execution risk, the estimated effect is at least twice its standard error, suggesting that the effect is not likely to have occurred by chance.

These results are similar to Ehrlich's. ${ }^{25} \mathrm{He}$ finds negative coefficients, ranging from -.039 to -.068 , for the six execution measures. In four cases, his negative coefficients are statistically significant. In

tained prior to 1934 since values of many variables lagged one year are required by the reduced form equation. The modified first differences obtained in the second stage of the regression analysis by the Cochrane-Orcutt procedure cannot be obtained prio: to 1935 since all exogenous and endogenous variables must be lagged one year. But with $\mathrm{PXQ}_{1-1}$ as the measure of execution risk (see $i d$. at 406-09), the earliest starting date is 1936 . The reduced form first stage equation requires that a lagged value of $P X Q_{1-1}$ be used to estimate arrest and conviction rates. but the first legitimate value of $\mathrm{PXO}_{\mathrm{I}-1}$ is that for 1934, not for 1933 , since the denominator of this measure incorporates values of homicides, arrests, and convictions lagged one year. This means that estimated arrest and conviction rates cannot be obtained before 1935 and that modified first differences cannot be estimated for periods beginning before 1936. Since Ehrlich gives 1935 as the beginning of the effective period, he may have used an erroneous (probably zero) value for $P X Q_{1-1}$ in the first stage estimation procedurc.

With $\mathrm{TXQ}_{1}$ as the measure of execution risk (see $i d$. at 406-09), the carliest beginning point for the effective period should be 1938. Since values of $T X Q_{1}$ depcnd on data from three prior years, the first values cannot be obtained before 1936; the first stage estimation of arrest and conviction rates with lagged $T X Q_{1}$ cannot be made for years earlier than 1937; and hence modified first differences cannot be calculated for effective periods starting earlier than 1938. If, as Ehrlich indicates, 1937 is actually used as the beginning date of the effective period, lagged $T X Q_{1}$ in the first stage equation will be an arbitrary (probably nonzero) value based on data from only two prior years (and a zero value for the third year).

$\mathrm{PXQ}_{1_{-1}}$ and $\mathrm{TXQ}_{1}$ are used more extensively than any of the other execution measures in Ehrlich's regression analyses, and in virtually all cases the effective period of analysis begins one year too soon. The following equations in both of his papers would appear to be misspecified, and therefore improperly estimated, in terms of the effective period of analysis: equations 3 and 4 in Table 4 of Ehrlich 1973, supra note 1 , at 53, and Table 3 of Ehrlich 1975, supra note 1, at 410; equations 2.5 in Table 5 of Ehrlich 1973, supra at 54; equations 1-6 in Table 6 of $i d$. at 55, and Table 4 of Ehrlich 1975, supra at 410; and equations 3 and 4 in Table 7 of Ehrlich 1973, supra at 57.

We believe these equations are not simply mislabeled but are, in fact, improperly specified with respect to the effective period of analysis. With the data generated from information in Ehrlich's memorandum, supra note 15, we have estimated each of the above equations for its maximum proper effective period and for the apparently incorrect one indicated in Ehrlich's tabulations. In every case, we found that the results reported by Ehrlich correspond more closely with the estimates we have obtained for the incorrectly defined effective period. However, the resulting errors of estimation are probably small in magnitude since they enter the second stage regression results through one of 18 variables in the first stage estimation of arrest and conviction rates.

25. See Ehrlich 1975, supra note 1, at 409-13. 
addition, the relative strengths of the effects of arrest ( $\left.\mathrm{P}^{\circ} \mathrm{a}\right)$, conviction $\left(\mathrm{P}^{\circ} \mathrm{C} \mid \mathrm{a}\right)$ and execution $\left(\mathrm{P}^{\circ} \mathrm{e} \mid \mathrm{c}\right)$ are the same as Ehrlich reports. ${ }^{26} \mathrm{Ac}$ cording to Ehrlich, "[ $t]$ he regression results regarding the effects of $\mathrm{P}^{\circ} \mathrm{a}$, $\mathrm{P}^{\circ} \mathrm{C} \mid \mathrm{a}$, and $\mathrm{P}^{\circ} \mathrm{e} \mid \mathrm{c}$ constitute perhaps the strongest findings of the empirical investigation. Not only do the signs of the elasticities associated with these variables conform to the general theoretical expectations, but their ranking, too, is consistent with the predictions . ..."27 Thus, by reproducing the rank order of effects among arrest, conviction, and execution rates, we have replicated an especially important aspect of his regression results. ${ }^{28}$

\section{B. Temporal Specification}

If the results of a time series regression analysis are a faithful representation of underlying causal processes, the values of the estimated coefficients will be independent of the specific time period chosen for the analysis. Thus, if the values of the coefficients associated with the various measures of execution risk change substantially when they are estimated for alternative time intervals, the negative values reported in Table III are not a reliable basis for inferring that capital punishment has a deterrent effect on murder.

Ehrlich addressed this issue by repeating the regression analysis for selected subperiods. He performed seven regressions in which varying numbers of years were removed from the beginning of the time series and two analyses in which three years were dropped from the end of the series. These alterations in the effective period of analysis do not appreciably change the elasticities associated with execution risk. ${ }^{29}$ Ehrlich does, however, concede that the deterrent effects of arrest, conviction, and execution rates become weaker when as many as seven years are dropped from the recent end of the time series. ${ }^{30}$

We find that all empirical support for the deterrent effect of capital

20. Id.

27. Id. at 411 .

28. Our results are comparable to Ehrlich's in other respects (see appendix B, supra note 2 , for the full regression results). The elasticities associated with the alternative measures of execution risk are less in absolute magnitude than those associated with arrest and conviction rates, but relative to their standard crrors, they tend to fall between those of the arrest and conviction measures. In addition, the signs of the elasticities associated with the remaining causal factors are the same as those obtaincd by Ehrlich.

29. Elnrich 1975, supra note 1, at 410; Ehrlich 1973, supra note 1, at 55 .

30. Ehrlich 1973 , supra note 1 , at 70 . 
punishment disappears when the five most recent years are removed from the time series that Ehrlich selected for analysis. Table IV ${ }^{31}$ shows the estimated effects of execution risk on the criminal homicide rate for 10 periods with successively earlier ending dates. For the period ending in 1964, there are no statistically significant negative elasticities associated with the various measures of execution risk. For the period ending in 1963, the estimated elasticities have become positive in every case. Indeed, of the 24 coefficients reflecting the effects of execution risk for periods ending in 1963 and earlier, 20 are positive and only four are negative.

Furthermore, we find that the regression results are more adequate and consistent for the periods with earlier ending dates. The standard errors of the regressions are less, the $F$ and $R^{2}$ statistics are consistently higher, and the Durbin Watson statistics are generally more acceptable for the periods ending in 1960 and 1963 than for those ending in 1966 and $1969 . .^{32}$ In addition, the estimated coefficients for the other variables in the regression equations for the two shorter periods are

31.

Table IV

Estimated Effects of Execution Risk on the Criminal Homicide Rate for Effective Periods with Successively Earlier Ending Dates

(Variables in Natural Logarithms) ( $\mathrm{t}$ Values in Parentheses)

\begin{tabular}{|c|c|c|c|c|c|c|}
\hline \multirow{2}{*}{$\begin{array}{c}\text { Ending Date } \\
\text { of Effective } \\
\text { Period }\end{array}$} & \multirow[b]{2}{*}{$P X Q_{1}$} & \multicolumn{4}{|c|}{ Six Alternative Mreasures of Execution Risk } & \multirow[b]{2}{*}{$P \widehat{\mathbb{X}} Q_{1}$} \\
\hline & & $P X Q_{2}$ & $P \times Q_{1-1}$ & $T \times Q_{1}$ & $P D L_{1}$ & \\
\hline 1969 & $\begin{array}{r}-.018 \\
(-.69)\end{array}$ & $\begin{array}{r}-.068 \\
(-3.15)\end{array}$ & $\begin{array}{r}-.023 \\
(-1.12)\end{array}$ & $\begin{array}{r}-.059 \\
(-2.70)\end{array}$ & $\begin{array}{r}-.065 \\
(-3.45)\end{array}$ & $\begin{array}{r}-.004 \\
(-.113)\end{array}$ \\
\hline 1968 & -.026 & $\begin{array}{r}-.069 \\
-8.50\end{array}$ & -.030 & -.059 & -.069 & -.049 \\
\hline 1967 & $\begin{array}{r}(-.091) \\
-.031\end{array}$ & -.064 & $\begin{array}{r}-.061 \\
-.061\end{array}$ & -.064 & -.068 & -.060 \\
\hline 1966 & $\begin{array}{r}(-1.38) \\
-.020\end{array}$ & $\begin{array}{r}(-3.65) \\
-.055\end{array}$ & $\begin{array}{r}(-3.18) \\
-.053\end{array}$ & $\begin{array}{r}(-3.64) \\
-.050\end{array}$ & $\begin{array}{r}(-4.55) \\
-.056\end{array}$ & $\begin{array}{r}(-1.98) \\
-.013\end{array}$ \\
\hline & $(-1.00)$ & $(-3.79)$ & $(-3.31)$ & $(-2.88)$ & $(-3.40)$ & $(-1.59)$ \\
\hline 1965 & $\begin{array}{r}-.016 \\
(-.99)\end{array}$ & $-\frac{-.041}{(-1.51)}$ & $\begin{array}{r}.034 \\
(-1.20)\end{array}$ & $\begin{array}{l}-.025 \\
(-.98)\end{array}$ & $\begin{array}{l}-.037 \\
(-1.53)\end{array}$ & $\begin{array}{r}-.031 \\
(-1.41)\end{array}$ \\
\hline 1964 & $\begin{array}{r}.028 \\
(.91)\end{array}$ & $\begin{array}{r}-.021 \\
(-.70)\end{array}$ & $\begin{array}{r}-.017 \\
(-.58)\end{array}$ & $\frac{-.009}{(-.34)}$ & $\begin{array}{r}-.013 \\
(-.40)\end{array}$ & $\begin{array}{r}.013 \\
(.37)\end{array}$ \\
\hline 1963 & $\begin{array}{r}.057 \\
(1.77)\end{array}$ & $\begin{array}{r}.003 \\
.08)\end{array}$ & $\begin{array}{r}.003 \\
(.08)\end{array}$ & $\begin{array}{r}.065 \\
(1.63)\end{array}$ & $\begin{array}{r}.048 \\
(1.00)\end{array}$ & $\begin{array}{r}.037 \\
(1.02)\end{array}$ \\
\hline 1962 & $\begin{array}{r}.052 \\
(1.14)\end{array}$ & $\begin{array}{r}-.030 \\
(-.60)\end{array}$ & $\begin{array}{l}-.021 \\
(-.54)\end{array}$ & $\begin{array}{r}.060 \\
(1.30)\end{array}$ & $\begin{array}{l}.021 \\
(.35)\end{array}$ & $\begin{array}{r}.040 \\
(.83)\end{array}$ \\
\hline 1961 & $\begin{array}{l}-.015 \\
(-.28)\end{array}$ & $\begin{array}{l}.041 \\
(.67)\end{array}$ & $\begin{array}{l}.011 \\
(.29)\end{array}$ & $\begin{array}{r}.086 \\
(2.10)\end{array}$ & $\begin{array}{r}.050 \\
(1.02)\end{array}$ & $\begin{array}{l}-.019 \\
(-.33)\end{array}$ \\
\hline 1960 & $\begin{array}{l}.013 \\
(.24)\end{array}$ & $\begin{array}{l}.029 \\
(.52)\end{array}$ & $\begin{array}{l}.009 \\
(.25)\end{array}$ & $\begin{array}{r}.070 \\
(1.72)\end{array}$ & $\begin{array}{r}.067 \\
(1.36)\end{array}$ & $\begin{array}{l}.013 \\
. .22)\end{array}$ \\
\hline
\end{tabular}

32. See equations 1.1-6.4 in appendix B, supra note 2. These statistical measures are tests for the reliability of the regression results. 
generally closer in value than in the equations for the longer periods. ${ }^{33}$

Hence for the periods in which the model gives evidence of being more adequately specified, the regression analysis consistently shows a slightly positive-though not statistically significant-effect of execution risk on the homicide rate.

\section{Functional Form}

Seldom does an initial theoretical formulation, such as Ehrlich's economic model of the determinants of murder, unambiguously dictate the mathematical function which describes the true relationships among the variables. When the functional form is open to question or when the analyst wishes to establish the generality of his findings, he will typically examine regression results obtained under different assumptions about the form of the model.

Ehrlich assumes that the factors which determine the murder rate have a multiplicative effect. Adopting a standard regression technique, he uses logarithmic values of the variables, in order to transform this multiplicative relationship into an equivalent linear form suitable for regression analysis. ${ }^{3 *} \mathrm{He}$ reports that his regression results are not dependent on the specific assumptions he has made about the form of the relationships among the variables-that there is evidence of a deterrent effect even when he performs the regression analysis with the natural values of his variables (which corresponds to a linear rather than a multiplicative relationship among the variables).$^{35}$

Using the natural values of these variables, we have re-estimated the coefficients shown in Table IV. We show these results in Table $\mathrm{V} .^{36}$ There are, among the 60 estimates in Table $\mathrm{V}$, more positive than negative coefficients associated with the various measures of execution risk. Only two of them, both positive, are statistically significant. The direction and size of the estimated coefficients do not appear to be systematically affected by the choice of time period. In other words, the last few years of the time series, which are apparently responsible for the evidence of a deterrent effect when logarithmic

33. Not only does the evidence for deterrence disappear, but Ehrlich's more general theoretical formulation is weakened by our findings. When we examine the results for periods ending in 1964 or earlier, we find only three instances out of 30 possible results which conform to his rank order predictions of the relative strengths of the deterrence variables. See pp. 196-97 supra; appendix B, supra note 2.

34. See J. Johnston, Econometric Methods $47-50$ (2d ed. 1972); R. Wonnacott \& T. Wonnacotr, Econometrics $91-98$ (1970).

35. Ehrlich 1975, supra note 1, at 412-13; Ehrlich 1973, supra note 1, at 36-37.

36. When exccution risk and homicide rates are expressed in natural values rather than 
values are used, yield no such evidence with the natural values of the variables.

\section{Sources of Ehrlich's Deterrence Evidence}

We have seen that Ehrlich obtains evidence of a deterrent effect only by imposing highly restrictive conditions on his analysis. One might assume that this evidence of deterrence reflects either a strong deterrent effect operating exclusively in recent years or a more pervasive effect obscured by data inadequacies in the early years. We show instead that Ehrlich's evidence is strictly a statistical artifact, not the reflection of a deterrent effect over the entire period of analysis or the most recent subperiod.

in logarithms, the regression coefficients indicate the change in the homicide rate to be expected from a one unit change in execution risk. For example, a coefficient of -.00061 (for PXQ in the period 1935-1969) means that a reduction in the number of exccutions from 10 to nine (per 100 convictions for murder) can be expected to increase the homicide rate from 5.00000 to 5.00061 (per 100,000 population), or to add 12 homicides for a population of 200 million.

\section{Table V}

Estimated Effects of Execution Risk on the Criminal Homicide Rate for Effective Periods with Successively Earlier Ending Dates

(Variables in Natural Values)

(t Values in Parentheses)

\begin{tabular}{|c|c|c|c|c|c|c|}
\hline $\begin{array}{c}\text { Ending Date } \\
\text { of Effective }\end{array}$ & & Six $A l$ & ative Mea & of Exc & Rish & \\
\hline Period & $P X Q_{1}$ & $P X Q_{2}$ & $P X Q_{1-1}$ & $T X Q_{1}$ & $P D L_{1}$ & $P \widehat{\mathrm{X}} Q_{1}$ \\
\hline 1969 & $\begin{array}{r}.00008 \\
(.05)\end{array}$ & $\begin{array}{r}-.00061 \\
(-.73)\end{array}$ & $\begin{array}{r}.00132 \\
(1.02)\end{array}$ & $\begin{array}{r}.00135 \\
(.64)\end{array}$ & $\begin{array}{r}.00085 \\
(.43)\end{array}$ & $\begin{array}{r}.00051 \\
(.33)\end{array}$ \\
\hline 1968 & $\begin{array}{r}.00038 \\
(.25)\end{array}$ & $\begin{array}{r}-.00068 \\
(-.79)\end{array}$ & $\begin{array}{r}.00126 \\
(.96)\end{array}$ & $\begin{array}{r}.00134 \\
(.61)\end{array}$ & $\begin{array}{r}.00085 \\
(.41)\end{array}$ & $\begin{array}{r}.00053 \\
(.34)\end{array}$ \\
\hline 1967 & $\begin{array}{r}.00021 \\
(.16)\end{array}$ & $\begin{array}{r}-.00051 \\
(-.63)\end{array}$ & $\begin{array}{r}.00629 \\
(.56)\end{array}$ & $\begin{array}{r}.00106 \\
(.47)\end{array}$ & $\begin{array}{r}.00039 \\
(.18)\end{array}$ & $\begin{array}{r}.00016 \\
(.114)\end{array}$ \\
\hline 1966 & $\begin{array}{r}-.00023 \\
(-.20)\end{array}$ & $\begin{array}{r}-.00040 \\
(-.52)\end{array}$ & $\begin{array}{l}-.00013 \\
.(-.17)\end{array}$ & $\begin{array}{r}.00110 \\
(.54)\end{array}$ & $\begin{array}{r}.00016 \\
(.22)\end{array}$ & $\begin{array}{r}-.00016 \\
(-.38)\end{array}$ \\
\hline 1965 & $\begin{array}{r}-.00027 \\
(-.29)\end{array}$ & $\begin{array}{r}-.00027 \\
(-.40)\end{array}$ & $\begin{array}{r}-.00038 \\
(-.60)\end{array}$ & $\begin{array}{r}.00124 \\
(.81)\end{array}$ & $\begin{array}{r}.00087 \\
(.52)\end{array}$ & $\begin{array}{r}-.00053 \\
(-.55)\end{array}$ \\
\hline 1964 & $\begin{array}{r}.00009 \\
(.11)\end{array}$ & $\begin{array}{r}-.00024 \\
(-.37)\end{array}$ & $\begin{array}{r}-.00034 \\
(-.57)\end{array}$ & $\begin{array}{r}.00104 \\
(.78)\end{array}$ & $\begin{array}{r}.00123 \\
(.78)\end{array}$ & $\begin{array}{r}-.00004 \\
\left(-.0-\frac{1}{2}\right)\end{array}$ \\
\hline 1963 & $\begin{array}{r}.00026 \\
(.29)\end{array}$ & $\begin{array}{r}-.00019 \\
(-.28)\end{array}$ & $\begin{array}{r}-.00023 \\
(-.37)\end{array}$ & $\begin{array}{r}.00123 \\
(.87)\end{array}$ & $\begin{array}{r}.00189 \\
(1.10)\end{array}$ & $\begin{array}{r}.00022 \\
(.24)\end{array}$ \\
\hline 1962 & $\begin{array}{r}-.00030 \\
(-.38)\end{array}$ & $\begin{array}{r}-.00023 \\
(-.35)\end{array}$ & $\begin{array}{r}-.00032 \\
(-.56)\end{array}$ & $\begin{array}{r}.00058 \\
(.53)\end{array}$ & $\begin{array}{r}.00120 \\
(.80)\end{array}$ & $\begin{array}{r}-.00035 \\
(-.44)\end{array}$ \\
\hline 1961 & $\begin{array}{r}-.00032 \\
(-.50)\end{array}$ & $\begin{array}{r}.00027 \\
(.45)\end{array}$ & $\begin{array}{r}-.00003 \\
(-.05)\end{array}$ & $\begin{array}{r}.00147 \\
(1.35)\end{array}$ & $\begin{array}{l}.00216 \\
(2.00)\end{array}$ & $\begin{array}{r}-.00041 \\
(-.68)\end{array}$ \\
\hline 1960 & $\begin{array}{r}-.00004 \\
(-.06)\end{array}$ & $\begin{array}{r}.00041 \\
(.69)\end{array}$ & $\begin{array}{r}.00005 \\
(.09)\end{array}$ & $\begin{array}{r}.00139 \\
(1.30)\end{array}$ & $\begin{array}{r}.00235 \\
(2.17)\end{array}$ & $\begin{array}{r}-.00013 \\
(-.20)\end{array}$ \\
\hline
\end{tabular}

* Coefficients are rounded to five decimal places for natural values. 


\section{A. The Recent Years}

What is it about the middle and late 1960's which causes the execution variables to show negative effects on the homicide rate when they are in logarithmic but not in natural form? The answer lies in the opposing trends in the two variables and in the nature of the logarithmic transformation. The national homicide rate, as reported by the FBI, rose precipitously in the middle and late 1960's to levels well above those of the 1940's and 1950's. Indeed, between 1962 and 1969 the homicide rate rose almost 60 percent to a level exceeded only by the rate for 1933. At the same time, executions literally came to an end. Hence execution risk-the number of executions among those convicted of murder-took on extremely low values, approaching zero, in the middle and late $1960{ }^{\prime} \mathrm{s}^{37}$ A property of the logarithmic transformation is to emphasize variations at the lower range of a variable. For example, if execution risk is converted into logarithms, a difference between one and two executions per 1,000 convictions will be greater than a difference between 350 and 650 executions per 1,000 convictions. Consequently, the logarithmic transformation accentuates the decline in execution risk that occurred in the 1960's.

To show the effect of the logarithmic transformation on these low values of execution risk, we present in Table $\mathrm{VI}^{38}$ the corresponding logarithmic and natural values of one of the six measures of execution risk for the years from 1960 through 1969. The natural values of execution risk have dropped from about one percent in

37. There have been no executions since 1967. In order to extend the effective period of analysis through 1969, Ehrlich had to generate nonzero execution rates for the years after 1967, since the logarithm of zero is not defined. He did this by supplying one nonexistent execution for 1968 and 1969 in the calculation of PXQ. Ehrlich 1975, supra note 1 , at 409 n.b.

38.

Table VI

Logarithmic and Natural Values of Execution Risk (PXQ_) for Each Year 1960-1969

\begin{tabular}{|c|c|c|c|c|}
\hline & Lo & rithms & Natural & alues \\
\hline & $\begin{array}{c}\text { The Absolute } \\
\text { Value }\end{array}$ & $\begin{array}{c}\text { Standard } \\
\text { Deviations } \\
\text { from the Mean }\end{array}$ & $\begin{array}{c}\text { The Absolute } \\
\text { Value }\end{array}$ & $\begin{array}{c}\text { Standard } \\
\text { Deviations } \\
\text { from the Mean }\end{array}$ \\
\hline 1969 & -3.823 & -2.524 & .022 & -1.123 \\
\hline 1968 & -3.873 & -2.554 & .021 & -1.124 \\
\hline 1967 & -3.134 & -2.103 & .044 & -1.114 \\
\hline 1966 & -3.774 & -2.494 & .023 & -1.123 \\
\hline 1965 & -1.742 & -1.252 & .175 & -1.059 \\
\hline 1964 & -1.456 & -1.077 & .233 & -1.034 \\
\hline 1963 & -.642 & -.580 & .526 & -.911 \\
\hline 1962 & .174 & -.081 & 1.191 & -.630 \\
\hline 1961 & -.042 & -.214 & .959 & -.728 \\
\hline 1960 & .229 & -.048 & 1.257 & -.602 \\
\hline
\end{tabular}


the years 1960-1962 to less than .05 percent for the years 1966-1969. The values for the years after 1964 are all slightly more than one standard deviation below the mean for the entire period from 1933 to 1969. Putting execution risk in logarithmic form greatly accentuates the decline. The difference between 1960 and 1969 in logarithmic values (from .229 to -3.823 ) is more than three times the corresponding difference in natural values (from 1.257 to .022). In fact, for the period from 1966 to 1969, the logarithmic values of execution risk are all more than two standard deviations below their mean. Thus, by using logarithmic values of execution risk, Ehrlich gives considerably more weight in his regression analysis to the extremely low values of this variable after 1964 .

Ehrlich has stated that the recent behavior of arrest and conviction rates as well as that of execution risk plays an important role in his regression results. ${ }^{39}$ To examine the effect of using the logarithmic values of execution risk and the possibility that the logarithmic transformation of arrest and conviction rates may also influence the regression results, we present, in Table VII,40 simple correlations of the arrest, conviction, and execution rates with the criminal homicide rate; these are shown for logarithmic and natural values of the variables and for time intervals with successively earlier ending dates from 1969 through 1960. The data for the recent years have an extraordinary effect on the correlation between the logarithms of execution and homicide rates; adding the last five years reduces the correlation from .836 to .123 . In contrast, the recent data have much

39. Ehrlich 1973, supra note 1 , at 70 .

40.

Table VII

Correlations of Arrest, Conviction, and Execution Rates with the Homicide Rate for Effective Periods with Successively Earlier Ending Dates (Separately for Logarithmic and Natural Values of the Variables)

\begin{tabular}{ccccccc} 
& \multicolumn{2}{c}{$\begin{array}{c}\text { Arrest Rate } \\
\left(P^{\circ} a\right)\end{array}$} & $\begin{array}{c}\text { Conviction Rate } \\
\left(P^{\circ} c \mid a\right)\end{array}$ & \multicolumn{2}{c}{$\begin{array}{c}\text { Execution Rate } \\
\left(P Q X_{2}\right)\end{array}$} \\
$\begin{array}{c}\text { Effective } \\
\text { Periods }\end{array}$ & Logarithms & $\begin{array}{c}\text { Natural } \\
\text { Values }\end{array}$ & Logarithms & $\begin{array}{c}\text { Natural } \\
\text { Values }\end{array}$ & Logarithms & $\begin{array}{c}\text { Natural } \\
\text { Values }\end{array}$ \\
$1933-1969$ & -.809 & -.832 & -.504 & -.516 & .123 & .553 \\
$1933-1968$ & -.801 & -.818 & -.488 & -.496 & .270 & .644 \\
$1933-1967$ & -.793 & -.809 & -.492 & -.497 & .442 & .720 \\
$1933-1966$ & -.791 & -.808 & -.496 & -.499 & .563 & .758 \\
$1933-1965$ & -.792 & -.809 & -.496 & -.499 & .748 & .773 \\
$1933-1964$ & -.795 & -.813 & -.494 & -.497 & .806 & .772 \\
$1933-1963$ & -.806 & -.824 & -.488 & -.491 & .858 & .763 \\
$1933-1962$ & -.820 & -.837 & -.495 & -.500 & .857 & .750 \\
$1933-1961$ & -.819 & -.835 & -.505 & -.511 & .846 & .741 \\
$1933-1960$ & -.814 & -.831 & -.518 & -.526 & .836 & .729
\end{tabular}

For data sources, see Appendix, nos. 2-4. 
less effect on the correlation between the natural values of execution and homicide rates; adding the last five years reduces the correlation only from .729 to .553 .41 These years have virtually no impact on the correlations, in either logarithmic or natural form, of arrest and conviction rates with the criminal homicide rates. Thus, Ehrlich's evidence of deterrence rests heavily on the relationship between the values of execution risk and homicide rates for the years after 1964 .

This conclusion might suggest that the use of the death penalty at the very low levels of execution risk in the middle and late 1960's had a deterrent effect strong enough to produce a measurable effect over the entire period when these recent years are combined with earlier years. We examine this possibility in Table VIII. ${ }^{42}$ It shows annual changes in the homicide rate relative to national changes in the homicide rate for the period 1962 to 1968 among states that increased or decreased the number of executions imposed for murder. The relative changes in homicide rate are expressed in homicides per 100,000 people, and are obtained by subtracting the changes in the national homicide rate from changes in the individual states.

41. Note, in this connection, that Ehrlich's extension of the time series on execution risk from 1967 to 1969 by supplying executions for 1968 and 1969 in the calculation of PXQ, note 30 supra, reduces its correlation with the homicide rate in logarithmic values from 442 for 1933 to 1967 to .123 for 1933 to 1969 and in natural values from .720 to .553 for the same periods.

42.

Table VIII

Annual Changes in Criminal Homicide Rate Among States Which Have Increased and Decreased Executions Relative to Annual Homicide Rate Changes in the Nation as a Whole for the Period 1962-1968

\section{States Which Have \\ Decreased Executions}

Relative

Homicide Number Population

Annual Change Rate Change of States Proportion

1962-1963

$1963-1964$

$1964-1965$

$1965-1966$

$1966-1967$

1967-1968

$$
\begin{array}{r}
-.10 \\
.19 \\
-.41 \\
-.93 \\
.62 \\
-.23
\end{array}
$$

\begin{tabular}{|c|c|c|}
\hline \multicolumn{3}{|c|}{$\begin{array}{l}\text { States Which Have } \\
\text { Increased Executions }\end{array}$} \\
\hline $\begin{array}{c}\text { Relative } \\
\text { Rate Change } \\
\text { Homicide }\end{array}$ & $\begin{array}{l}\text { Number } \\
\text { of States }\end{array}$ & $\begin{array}{l}\text { Population } \\
\text { Proportion }\end{array}$ \\
\hline-.03 & 6 & .17 \\
\hline-.33 & 3 & .06 \\
\hline .88 & 4 & .05 \\
\hline .50 & 1 & .01 \\
\hline .09 & 2 & .11 \\
\hline- & - & - \\
\hline
\end{tabular}

$\begin{array}{rl}14 & .44 \\ 8 & .33 \\ 3 & .13 \\ 4 & .05 \\ 1 & .01 \\ 2 & .11\end{array}$

States imposing executions for murder during this period were identified in Appendix A of W. Bowers, Executions in AMerica 200-401 (1974); criminal homicides annually by state were obtained from FBI, Uniform Crime Reports for the United States (Table 3, 1962-1964; Table 4, 1965-1968); annual population estimates by state were taken from U.S. Bureau of the Census, Dep't of Commerce, Current Population Reports: Population Estimates and Projection (Scr. P-25, No. 460, Oct. 1971) (1962-1968). Changes in homicide rates for groups of states that increased and decreased executions are essentially the average of the annual changes in the states that comprise the group weighted by their respective population sizes. The data for these states are directly comparable with the national figures in the Uniform Crime Reports. 
If execution risk had a deterrent effect, states with declining numbers of executions would show a relative increase in homicide rate, and states with rising execution levels would show a relative decrease in homicide rate. But Table VIII demonstrates that there is no such pattern in the years since 1962. Among states which decreased executions, the homicide rate rose more than the national figure for two of the periods ${ }^{43}$ and less than the national figure for four. Among states that increased executions, the change in homicide rate was below the national change in one comparison, very nearly the same in one case, and actually above in three of the five comparisons.

Table VIII also shows that the use of capital punishment during this period was restricted increasingly to a small minority of states. After 1964, no more than five states imposed executions in a single year, none of them imposed more than one execution per year, and none imposed executions two years in a row. In this situation, the national homicide rate cannot be expected to reflect possible deterrent effects presumed to occur primarily in the jurisdictions that actively use the death penalty. Thus, apart from problems of temporal specification and functional form, it would have been more appropriate, in view of the progressively restricted use of capital punishment in the nation, for Ehrlich to have shortened the effective period of analysis by removing the years after 1963 , when no more than 10 percent of the states imposed executions, than to have extended the period of analysis two years beyond the end of executions in the United States.

\section{B. The Early Years}

We have already described the unreliability of data for the 1930's. By reproducing his regression analysis for effective periods with later beginning dates, Ehrlich may have hoped to diminish the effects of measurement error in these early years. But he has thereby given greater weight to the years after 1964, which are responsible in the first place for his evidence of a deterrent effect.

To determine the effects of measurement error in the early years, we must first remove the idiosyncratic recent years, and then successively drop years from the beginning of the time series. Accordingly, we have performed regressions for periods with 1963 as the ending date and with successively later beginning dates from 1935 through

43. However, one of these two periods, 1966-1967, involves only one state, representing one percent of the population. 
1940. The estimated coefficients for logarithmic and natural values of two measures of execution risk are shown in Table IX. ${ }^{44}$

We know from Tables IV and V that the elasticities associated with execution risk for effective periods ending in 1963 and earlier are more often positive than negative, though usually not statistically significant. In Table IX, the coefficients are again predominantly positive, and become even more so as years are successively dropped from the beginning of the time series. In fact, the effective periods beginning in 1938, 1939, and 1940 show positive effects for execution risk in all 12 cases. These positive coefficients are, of course, absurd from the viewpoint of the deterrence hypothesis, although they may not be altogether meaningless. ${ }^{45}$ They do, however, indicate unambiguously that data inadequacies in the early years of the time series have not obscured deterrent effects of capital punishment. Indeed, by all indications there are no deterrent effects to obscure.

44.

Table IX

Estimated Effects of Execution Rish on the Criminal Homicide Rate for Effective Periods Ending in 1963 With Successively Later Beginning Dates (Separately for Variables in Logged and Unlogged Form)

(t Value in Parentheses)

\begin{tabular}{|c|c|c|c|c|}
\hline $\begin{array}{c}\text { Beginning Dale } \\
\text { of Effective }\end{array}$ & $\log$ & ms & Natu & altues \\
\hline Period & $P \times Q_{t-1}$ & $P \widehat{X} Q_{1}$ & $P \times Q_{1-1}$ & $P \widehat{X} Q_{1}$ \\
\hline 1935 & $=$ & $\begin{array}{r}.037 \\
(1.02)\end{array}$ & - & $\begin{array}{r}.000219 \\
(.24)\end{array}$ \\
\hline 1936 & $\begin{array}{l}.003 \\
(.08)\end{array}$ & $\begin{array}{l}.034 \\
(.95)\end{array}$ & $\begin{array}{r}-.000225 \\
(-.37)\end{array}$ & $\begin{array}{r}.000082 \\
(.08)\end{array}$ \\
\hline 1937 & $\begin{array}{l}.007 \\
(.19)\end{array}$ & $\begin{array}{r}.038 \\
(1.02)\end{array}$ & $\begin{array}{r}-.000079 \\
(-.12)\end{array}$ & $\begin{array}{r}-.000004 \\
(-.00)\end{array}$ \\
\hline 1938 & $\begin{array}{l}.038 \\
(.91)\end{array}$ & $\begin{array}{l}.033 \\
(.95)\end{array}$ & $\begin{array}{r}.001147 \\
(1: 10)\end{array}$ & $\begin{array}{r}.000833 \\
(.64)\end{array}$ \\
\hline 1939 & $\begin{array}{r}.062 \\
(1.39)\end{array}$ & $\begin{array}{r}.061 \\
(1.73)\end{array}$ & $\begin{array}{r}.001858 \\
(1.35)\end{array}$ & $\begin{array}{r}.001772 \\
(1.20)\end{array}$ \\
\hline 1940 & $\begin{array}{r}.095 \\
(1.95)\end{array}$ & $\begin{array}{r}.056 \\
(1.56)\end{array}$ & $\begin{array}{r}.004581 \\
(3.03)\end{array}$ & $\begin{array}{r}.001848 \\
(1.19)\end{array}$ \\
\hline
\end{tabular}

Table IX presents the effects of two measures of execution risk, $P X Q_{1-1}$ and $P \widehat{X} Q_{1}$. $P X Q_{1-1}$ is the measure used most frequently by Ehrlich, and $P \widehat{X} Q_{1}$, of all the measures, is least biased by measurement error since its one year lagged homicide rate is only one of 18 variables that figure in its estimation. Equations 13.1-16.3 of appendix B, supra note 2, present detailed regression results for selected periods beginning in 1936, 1938 , and 1940 .

45. The possibility that because of a "brutalizing effect," capital punishment may encourage rather than deter murders is beyond the scope of this paper but is considered in Bowers \& Pierce, supra note 2. In particular, we discuss the meaning of the positive regression coefficients we obtained when we substituted the number of executions for execution risk. 


\section{Conclusion}

We have shown that Ehrlich's findings are not a reliable basis for inferring the effects of capital punishment on the criminal homicide rate. Flaws in Ehrlich's data cast doubt on the ability to perform meaningful regression analysis. The analysis itself yields evidence of a deterrent effect only by relying on the unusual nature of the years after 1964 and on the logarithmic transformation of the data. When the analysis is performed for more appropriate periods, the hypothesis that the death penalty deters murders finds no support.

\section{APPENDIX}

Specific Data Sources Used in the Replication of Ehrlich's Regression Analysis

1. $\left(\frac{Q}{N}\right)^{\circ}$ Criminal Homicide Rate $=$ Number of Criminal Homicides per year $/ a n$ nual civilian population.

(a) $Q=$ Annual number of murders and nonnegligent manslaughters from 1933 to 1969 . Revised figures (1971) provided by the FBI.

(b) $\mathrm{N}=$ Civilian population of the United States in 1,000's from 1933 to 1969. U.S. Bureau of the Census, Dep't of Commerce, Current Yopulation Reports: Population Estimates and Projections Tables 3, 4 (Ser. P-25, No. 499, May 1973).

2. Poa Clearance Rate for Criminal Homicide $=$ Fraction of murders and nonnegligent manslaughters cleared by arrest. FBI, UNIForar Criate REPORTs For THE UNITEd States (1933-1969).

3. ${ }^{3 \circ} \mathrm{cja}$ Conviction Rate for Criminal Homicides $=$ Fraction of individuals found guilty as charged for murder and nonnegligent manslaughter. 1936-1969; id. After 1962 separate estimates are reported, in the Uniform Crime Reports annual bulletin. Estimates from the time series which is continuous orer the 1936 to 1969 period were chosen. These estimates were generally based on larger population bases. The value for 1961 is the average of the 1960 and 1962 estimates. 1933-1935: values 1933 to 1935 were obtained from Ehrlich (Ehrlich 1973, supra note 1, Figure 1).

4. Poe Execution. Risk for Criminal Homicide (PXQ, $\mathbf{P X Q}_{2}, \mathbf{P X Q}_{\mathfrak{x}-1}, \mathrm{TXQ}_{1}$, $\mathrm{PDL}_{1}, \mathbf{P} \widehat{\mathrm{X}} \dot{Q}_{1}$.) The measures of exccution risk are all variations of the form $\frac{\mathrm{E}}{\mathrm{C}}$, where $\mathrm{C}=\mathrm{Q} \cdot \mathrm{P}^{\circ} \mathrm{a} \cdot \mathbf{P}^{\circ} \mathbf{C} \mid \mathbf{a}$.

(a) $\mathrm{E}=$ The number óf executions for murder. U.S. Bureau of Prisoss, Dep't of Justice, National Prisoner Statistics Bulletin Table 1 (No. 46, Aug. 1971).

(b) $\mathrm{C}=$ Number of convictions for murder.

(c) $Q=$ The annual number of criminal homicides as defined in 1(a).

(d) $\mathrm{Po}^{\circ}, \mathrm{P}^{\circ} \mathrm{c} \mid \mathrm{a}$ are as defined in 2 and 3. 
5. L Labor Force Participation Rates:

for $1940-1969 \mathrm{~L}=\frac{\mathrm{CL}}{(\mathrm{TN}-\mathrm{TL}+\mathrm{CL})}$

for $1933.1939 \mathrm{~L}=\frac{\mathrm{CL}}{(\mathrm{N}-\mathrm{P} 13)}$

(a) $\mathrm{CL}, \mathrm{TL}=$ The civilian and total labor force in 1000's from 1933 to 1969. U.S. Bureau of Labor Statistics, Dep't of Labor, EMployment and Earnincs Table A-1 (Jan. 1971).

(b) $\mathrm{IN}=$ Total noninstitutional population from 1940 to 1969 . Id.

(c) $\mathbf{N}=$ Annual civilian population as defined in $\mathbf{l}(\mathrm{b})$.

(d) P13 = Annual population 13 ycars old and under from 1933 to 1939. U.S. Bureau of the Census, Dep't of Commerce, Current Population Reports: Population Estimates axd Projections (Ser. P-25, No. 311, July 1965).

6. U Unemployment Rate of the Civilian Labor Force, 1933 to 1969. EMPLOYMENT AND EARnings Table A-1, supra 5(a).

7. A Fraction of the Resident Population 14 to 24 Years of Age.

$A=\frac{\text { Pl424 }}{\text { RP }}$

(a) P1424 $=$ Number of persons 14 to 24 years of age in the resident population.

1933-1939: Current Population Reports, supra 5(d).

1940-1949: U.S. Bureau of the Census, Dep't of Commerce, Current Population Reports: Population Estimates and Projections Table 1 (Ser. P-25, No. 98, Aug. 1954).

1950-1959: id. Table 1 (Ser. P-25, No. 310, June 1965).

1960-1969: id. Table 2 (Ser. P-25, No. 519, Apr. 1974).

(b) $\mathrm{RP}=$ Resident population in 1000 's.

References same as given in (a) for each of the respective time periods.

8. Y Friedman's Estimate of Real Permanent Income per Capita. The following equation was used to compute $\mathrm{Y}$ :

$\mathrm{Y}_{\mathrm{t}}=(.330) \mathrm{Y}_{\mathrm{t}-1}+(.226) \mathrm{Y}_{\mathrm{t}-2}+(.154) \mathrm{Y}_{\mathrm{t}-3}+(.106) \mathrm{Y}_{\mathrm{t}-\mathrm{t}}+$

(.072) $Y_{t-s}+(.049) Y_{t-s}+(.033) Y_{t-\tau}+(.023) Y_{t-s}$

(a) The weights in the above equation were obtained from $E$. Karni, The Value of Time and the Demand for Money, 1971, Table 33 (unpublished doctoral dissertation, Univ. of Chicago).

(b) $Y_{t-1}$ through $Y_{t-8}$ are logarithmic estimates of per capita real national income for the years 1925 to 1969 . The national income figures werc provided by E. Karni. Population figures for per capita estimates were obtained from:

1925-1929: CuRrent Population Reports, supra 1(b), Table 4.

1930-1968: U.S. Dep't of Commerce, Survey of Current Business Tablc 7.6 (July 1969).

(c) The per capita income was measured in terms of 1919 dollars using a price deflator obtained from source (a).

9. NW Percent of Nonwhite Residential Population.

References same as given in $\boldsymbol{t}(\mathrm{a})$ for each of the respective time periods.

10. N Civilian Population in 1000's.

References same as given in $1(b)$. 
11. XGOV Per Capita Real Expendiutes on All Governments in Millions of Dollars. $\mathrm{xGOV}=\frac{(\mathrm{FE}+\text { SLE-D })}{\mathrm{RP}^{*} \mathrm{PD}^{* 10}}$

(a) $\mathrm{FE}, \mathrm{SLE}=$ Federal and state/local expenditure on all governments. 1933-1938: U.S. Dep'T OF Comarerce, Historical Statistics of the U.S.: Colonial Times to 1957 (1960).

1939-1965: U.S. Dep't of Commerce, The Nutional Income and ProdvCt Accounts of the United States, 1929-1965 Statisticil T.ibles (1966). 1966-1969: U.S. Dep't of Commerce, Strvey of Current Business (July 1970).

(b) $\mathrm{D}=$ National defense expenditures.

1933-1938: U.S. Dep't of Comimerce, Historical Statistics of the U.S.: Colonial Trmes to 1957, supra (a).

1939-1952: (purchases of goods and services). National INcome AND Prodvet Accovnts of the United States, supra (a), Tables 1.1.

1953-1969: (purchases of goods and services). SuRvey of CuRRENr BustNess, supra (a), Table 3.10 .

(c) $\mathbf{R P}=$ Residential population as defined by $7(\mathrm{~b})$.

(d) $\mathrm{PD}=$ Implicit price deflator for all governments.

1932-1965: National Income and Product Accounis of the United States, supra (a), Table 8.4.

1966-1969: SURveY of CuRRENT Business, supra (a).

12. XPOL $\mathrm{X}_{-1}$ Per Capita Real Expenditures on Police Lagged One Y'ear in Dollars.

XPOL $=\frac{\text { POLE* } 100,000}{\mathrm{RP} * \mathrm{PD}}$ where

(a) POLE $=$ Total police expenditure.

1932-1966: 6 U.S. Bureau of the Census, Dep't of Commerce, 1967 CenSUS OF GOVERNMENTS, No. 5, at 36 (1969).

1967-1969: U.S. Bureau of the Census, Governmental Finances in 196970, at 15 (1971).

(b) $\mathrm{RP}=$ Residential population as defined in 7 (b).

(c) $\mathrm{PD}=$ Price deflator as defined in 11 (d).

13. Alternative Vital Statistics Estimates of Homicide.

$\mathbf{Q}=$ Annual number of willful homicides (minus the annual number of executions after 1948, when the two mortality categories were combined).

1933-1936: U.S. Bureau of the Census, Dep't of Commerce, Mortality StATISTICS (1933-1936).

1937-1969: U.S. Bureau of the Census, Dep't of Commerce, Vital Statistics of the United States (1937-1945); U.S. Public Health Serv., Dep't of Health, Education, and Welfare, Vital Statistics of the United States (1946-1969). 